\title{
Community-Based Water Systems: Preserving Livelihood, Ecology, and Community
}

\author{
David S. Henkel ${ }^{1}$ \\ Professor Emeritus of Planning \\ University of New Mexico, United States
}

\section{Abstract}

In the high desert region of the southwestern United States, historical Spanish colonial and native Pueblo settlements long relied upon community-based water collection and distribution systems for irrigation and domestic use.

This paper adopts a community-based planning approach to examine the ways in which the community water and irrigation systems - the acequias - today contribute to the maintenance of the cultural landscape and ecological balance in the face of development pressures on traditional land use and natural resources. The formal authority of the acequias - associations of irrigators maintaining and operating irrigation channels - as political subdivisions of the state provide a means for coordinated regional resource planning in concert with state and local government, although challenged by powerful economic and political interests.

Keywords: community identity, irrigation, rural infrastructure, water rights

\section{Introduction}

In the precolonial period, the goal of human settlement in the southwestern desert region of the United States was survival, with success dependent on adaptation to the limits of natural systems largely through cooperative social mechanisms. The limiting resource was water.

The political economy under the crown of Spain in New Mexico (1585-1821) emphasized protection of wealth-producing lands in central Mexico by settling the northern frontier as a buffer against incursions from French and particularly American interests. Success depended upon colonists holding territory for the crown. Although some surplus wealth was derived from the settlements, their

1 Author contact: cymro@unm.edu. 
primary purpose was defense. Social solidarity was based upon mutual aid for subsistence agricultural production and for defense. The limiting resource was water for irrigation and household use.

During the brief Mexican period (1821-1848), state authority was distant but the political economy was based on early mercantilism. The Mexican state recognized the threat posed by the westward expansion of the young United States. Policy aims were to neutralize the external pressure and solidify occupation through the Indo-Hispano presence.

During both the Spanish and Mexican periods, successful settlement patterns depended upon observing the limits of the natural system, adaptation to adverse climatic and political conditions, the development of mutual aid mechanisms for labor and defense, and concentration on subsistence production of primary resources. Human settlements depended on a production system that respected the carrying capacity of the land. Customary practices governing water rights evolved at the local level, though theoretically subject to Spanish and Mexican governance principles (Simmons, 1969).

With the conquest of New Mexico in the US-Mexican war (1846-1848), new principles of political economy were introduced to the region. The political purpose was to establish dominion and solidify the national territory; the economic purpose was production of surplus wealth. Initially the relationship between human settlements and their natural surroundings was affirmed by treaty, and the early territorial period saw the wholesale adoption of customary practice associated with water by the new authorities. Gradually, however, Anglo-American law insisted upon documentary proof of title, acceptance of feesimple property ownership ${ }^{2}$ and the severability of water rights from irrigated land, and standardized regulatory practices. These militated against those earlier flexible arrangements whose purpose was the survival of communities rather than optimization of resources to benefit the few (Tyler, 1995).

\section{Context and key issues}

The fifth-largest of the 50 United States, New Mexico comprises six life zones from desert to tundra, and is characterized by extreme aridity that limits most human settlements to a half dozen river valleys and the drainages that feed into them. The predominance of upper Chihuahuan and upper Sonoran desert in riparian areas is fed by 20-30 millimeters annual precipitation, with variability due to El Niño and La Niña Southern Oscillation, in addition to long-term cycles of drought currently exacerbated by anthropogenic causes.

2 'Fee simple' refers to complete ownership of real property without restrictions - it comes from common law and is distinguished from lands granted by the crown, which could have been subsequently encumbered. 
The region's earliest inhabitants arrived about 15,000 B.C.E., succeeded by settlers from Mexico in the late 16th century, and subsequently by immigrants from the United States in the 19th century. The United States wrested the territory from the Republic of Mexico in 1848, along with Texas, Arizona, and large portions of California, Nevada, Utah, and Colorado-in sum, about 50 percent of Mexico's national territory.

The population of slightly more than 2 million is principally concentrated along the Rio Grande and the Pecos and San Juan rivers. New Mexico is a "minority majority" state, with several major living language traditions (indigenous Puebloan and Athapaskan, Mexican Spanish, English) and political control in the hands of no one group. It is the only one of the United States in which a language other than English has formal standing in courts of law.

Economic resources have historically been largely agricultural, along with timber, mineral products, and more recently fossil fuels and uranium. Industrial production is slight and is concentrated in two of the larger cities, Albuquerque and Las Cruces.

A recurrent theme in New Mexico's history has been the preservation of cultural identity in the face of powerful forces from the outside - first the Spanish empire and its successor Mexican republic, and then the hegemonic forces of the young United States, with local inhabitants struggling to maintain social cohesion as newcomers occupied territory already in use. The ecology of the region has constrained the range of economic strategies available, contributing to the intensity of the social dynamics and requiring a high degree of adaptability in political, social, and economic forms.

\section{The acequia culture}

The New Mexican irrigation ditch systems and the associations of irrigators who maintain and use them are both referred to by the Spanish term acequia, an adoption of the Arabic as-sāqiya (Figure 1). Before the penetration of Spanish and Mexican immigrants in the late 16th century, the indigenous people of the region had utilized local irrigation practices and attendant social organization (DunbarOrtiz, 2007). The addition of Iberian technology brought by settlers under Spain joined with and extended the earlier practices (Rivera \& Glick, 2002). 


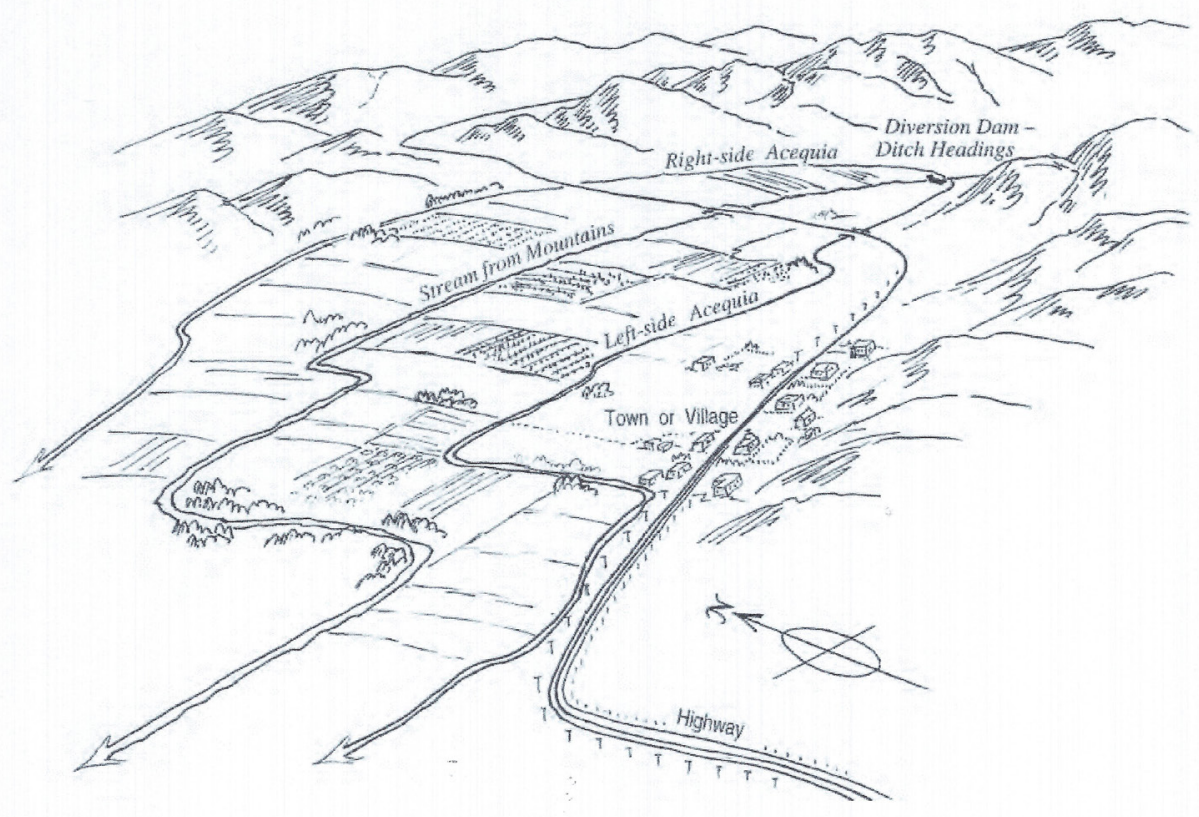

\section{Figure 1. Schematic rendering of an acequia system}

Source: Fort et al. (2012, p. 5-1). Reproduced with permission.

Both the indigenous and European systems recognized the need for social cooperation in acequia construction and maintenance, along with regulating mutual access during the times of water shortage that were not infrequent. Both systems fostered protection of the water from contamination, and recognized the ecological role of irrigation in maintaining soil moisture, promoting the biological health of the riparian habitat, and strengthening vegetation cover (Ebright, 2001; Meyer, 1984; Van Ness, 1987).

Local interests were served by improved conditions for human survival and natural resilience. The means to these ends rested in a set of social and technological practices that addressed the entire natural system. The practices evolved over time based upon keen observation, repetition, and modification in this water commons transmitted across generations, and reinforced by religious political institutions. Thus emerged the concept of an acequia culture (Ostrom, 1990; Rivera, 1998) (Figure 2). 


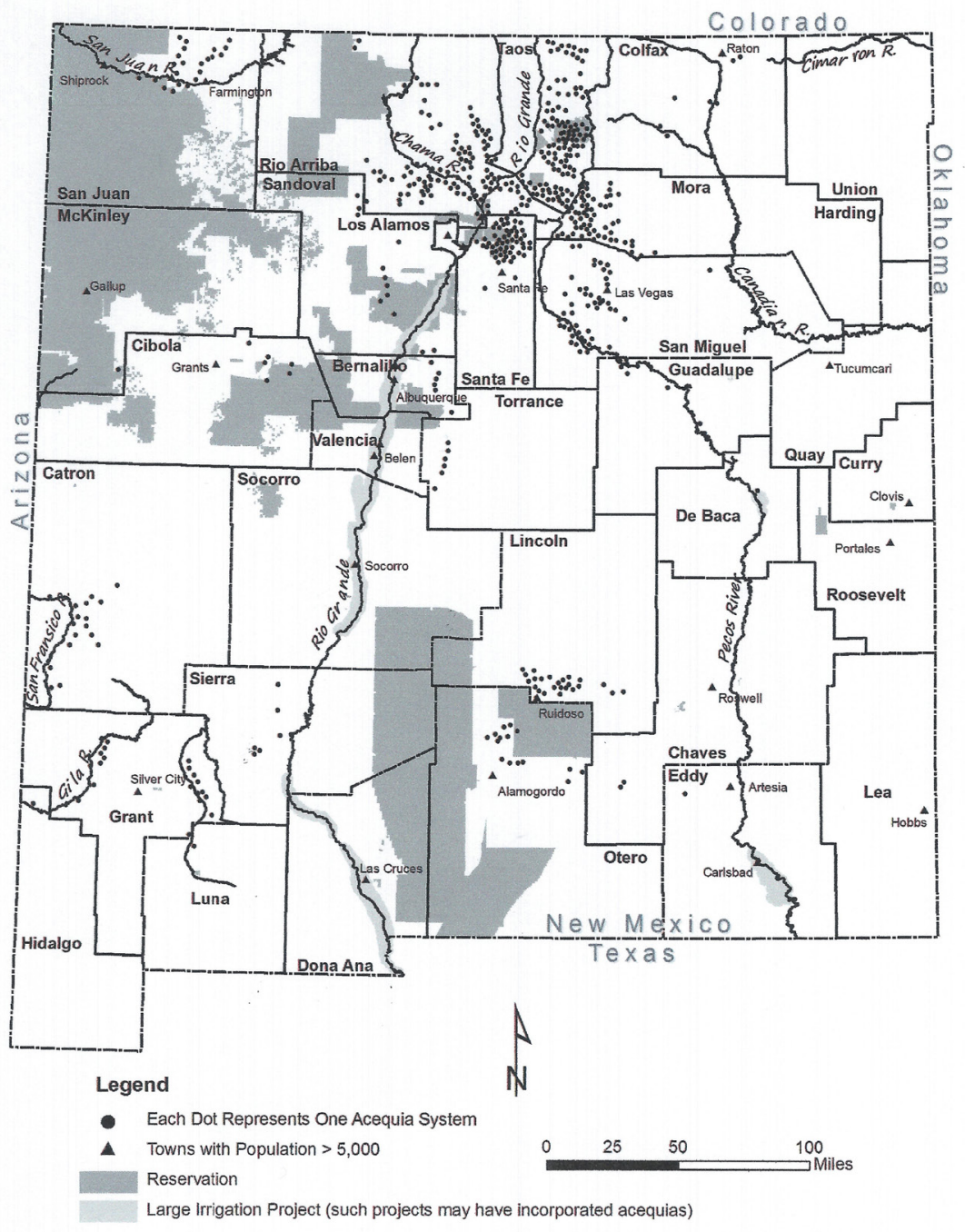

\section{Figure 2. Distribution of acequia systems in New Mexico}

Source: E. Zeiler (2013) (based on Fort et al. 2012, p. 5-7). Reproduced with permission. 


\section{Dependent variables: Functionality, mutuality, legitimacy}

Acequia culture is characterized by the dynamic interrelationship of three elements: the functionality of the water delivery system, the mutuality required within and between local social groups for management of the community ditches, and the legitimacy of the conditions under which water is appropriated and distributed.

Functionality includes provision of water (diversion from the main drainage), effective irrigation (allocation), and ecological health (ecosystem services and return flow). Mutuality comprises management of the water resources, joint performance of ditch maintenance, shared water allocation during times of scarcity, and reinforcement of the social fabric by exchange of labor. Legitimacy is defined by formal agreement over the allocation of water, honoring relative seniority (prior rights), and acknowledging law and custom as foundational principles.

The contours of functionality, mutuality, and legitimacy have varied with local practice under changing environmental conditions, from drought to surplus. They have also changed due to the nature of external state authority and the motives for territorial control in different historical periods.

\section{Independent variables: State policy and legal instruments}

The three dependent variables were affected by the intended purposes served by the system, varying with the dominant sociopolitical arrangements. Indigenous societies and local groups of incoming settlers were primarily concerned with survival, and their social organization, technology, subsistence economy, and decision-making practices were directed to that purpose. The concerns of the Spanish crown and its successor Mexican republic were those of dominion and of using the settled northern borderlands to protect an economically more valuable heartland to the south, with a modest return on agricultural products and raw materials. The Anglo-American influence directed itself to surplus production and commerce.

Similarly, the indigenous and settler regulation of access to water for domestic use, irrigation, and watering of livestock relied more upon locally evolved customary practices than on codified legal forms-notwithstanding the promulgation of formal requirements of settlement and land use practices by the Spanish crown and the Mexican state. The shift to formal civil law as the guiding principle for allocation and use of water occurred when New Mexico became a territory of the United States under the terms of the 1848 treaty of Guadalupe Hidalgo concluding the US-Mexico War. 


\section{Intervening variables}

There are two classes of intervening variables external to the acequia production system: those creating increased demands for available water, and those affecting rates of consumption.

The historical variability in climate conditions has affected the density and distribution of populations, through effects on the carrying capacity of the local habitat (Cook et al., 2009; Phillips et al., 2011). Current recognition of climate change (IPCC, 2007) suggests new magnitudes in the near future.

The number of people inhabiting the region has likewise affected the water resources available for human settlements, and has stimulated the competition for water during periods of drought. Furthermore, since the beginning of the Anglo-American occupation of the region there has been a steady population shift from rural to urban areas creating more intense demand of water for residential, commercial, and industrial uses.

The legal obligation to deliver specified volumes of water to downstream users under formal compacts with neighboring states and the Republic of Mexicoeven during times of drought - is a third factor affecting availability of water to the local natural systems and human environments.

Consequently, the economic strategies of the local inhabitants have also shifted over time from subsistence agriculture to natural resource extraction, to commercial production of value-added goods. These changes have altered the scale of demand for water, and have been accompanied by important changes in technology that have increased the speed and volume of groundwater extraction in addition to the ease of planting, harvesting, mining, and logging. The modern market economy has opened up employment options available to local people, contributing to the relocation of rural populations to urban areas.

\section{The acequia landscape: Indigenous, Spanish, and Mexican}

The acequia culture has evolved against a somewhat constant (except for drought cycles) physical backdrop but a more dynamic social context.

Tree ring data has demonstrated drought cycles occurring with periodic intensity over the previous 800 years (Cook et al., 2009). This has been accompanied by dislocation of populations and intense restrictions on agricultural production. Thus inhabitants of the region have had to adapt to severe changes, only partly alleviated by complex, pre-industrial irrigation technologies and social mobilization strategies for joint labor to construct and maintain the irrigation works. From earliest times, the social institutions with authority for organizing 
labor and allocating and distributing water have been based on very localized customary arrangements that persisted until the unitary state became dominant with the imposition of Anglo-American legal principles in the middle of the 19th century. Even then, local custom has continued to play a major part in the organization and operations of acequia associations, including their resistance to strict adherence to seniority of rights in times of water scarcity (Dunbar-Ortiz, 2007; Ebright, 2001).

Water rights under Spain and Mexico were rights of use rather than of property. This perspective allowed water resources critical to the survival of human settlements to be shared during times of scarcity, allowing all to survive. Senior and junior rights during the Spanish colonial period distinguished between standing access and access to 'surplus' irrigation rights. The goal was survival of the entire group (Rivera \& Glick, 2002; Greenleaf, 1972; Meyer, 1984; Simmons, 1972).

Traditional irrigation systems provided for livelihood, social solidarity, and environmental health. Water carried in community irrigation ditches supplied households, livestock, croplands, and eventually small grain mills (Brown and Rivera, 2000; Rivera, 1998).

\section{The impact of Anglo-American law}

The indigenous, Spanish, and Mexican cultures stressed balanced relationships between water users. The focal point was on survival and the perpetuation of social relationships between water users. In doing so, customary usage addressed the natural as well as the human environment. Anglo-American principles, and their concomitant values embedded in civil law, were more concerned with the human aspects of water rights and the impact on nature. Eventually, this was reinforced by a sense that water was to be treated as a commodity or property right, with monetized values determining its worth. Under this assumption, the value of water rights was to be defined by the marketplace.

The legal code imposed by the occupying military authorities preceded laws passed by the territorial legislature. It adopted the legal principles governing water rights from the Spanish and Mexican periods and integrated them into regulations governing their use in the newly acquired territories. In 1851 and 1852 the territorial legislature passed laws governing water rights and water use based upon the preceding practices of the Spanish and Mexican periods. While other statutes were crafted, up until the beginning of the 20th century most of the water law in New Mexico was based upon these historical antecedents. 


\section{Federal law and jurisprudence}

Although Spanish practice had included the concept of priority right, it was balanced by the practice of sharing water during times of scarcity. That is, even those with senior rights yielded allocation of water so that all users could survive. With the advance of Anglo-European legal principles, a more absolute practice was introduced: in times of scarcity, a "priority call" could exclude the holders of junior water rights completely. Although the Office of the State Engineer has been consistently reluctant to make such a "priority call," the legal possibility still exists - leaving the holders of junior water rights in an uncertain position.

Under laws introduced since statehood in 1912, holders of water rights can lose them if they do not use them in a four-year period. Although forfeiture is rare, it is a constant concern for those who for whatever reason are unable to irrigate or to put the water rights to which they are entitled to beneficial use. Water rights that are not used over a substantial period of time can be considered abandoned and subject to reallocation to other applicants. The principle here is that water is such a precious resource that lack of use is considered wasteful and therefore a reason to reassign those rights to users who would put them to use and better serve the public welfare.

Another concept introduced under Anglo-American law was that water rights could be severed from the land to which they had been assigned for purposes of irrigation. Originally, water rights "followed" the land. It was not conceivable to early settlers that water rights could be treated otherwise. But in the commercial frame of reference of Anglo-American practice, water rights could be seen as commodities, therefore subject to sale. Thus, a market for water rights was created and continues to exert pressure on the historical connection between water and land. For older holders of water rights, the value of those rights can constitute the equivalent of a pension to carry them through old age. Similarly, possessors of water rights who do not have adequate financial capital can find the increasingly greater cash value to be irresistible in paying for education, home construction, or the acquisition of inputs for productive purposes (Clark, 1987; Van Ness, 1987).

At the regional level, it was recognized from the early 20th century that the planned allocation of surface water resources of the major river systems of the Southwest were necessary for the continuance of settlements and agricultural production. Consequently, interstate compacts and international treaties were devised in order that the water could be distributed in an orderly fashion throughout the region. These included the Colorado River Compact (1922); the Rio Grande Compact (1938); the 1944 treaty between the United States and Mexico governing use of water from the Rio Grande, and the Colorado and 
Tijuana rivers; the Pecos River Compact (1948); and the Canadian River Compact (1971). In 1983, the United States and Mexico concluded the La Paz Agreement that addressed the quality of the water delivered from the United States to Mexico under the terms of the 1944 treaty. All of these interstate compacts and international agreements overrode the authority of local water policy in New Mexico, requiring the delivery of water downstream as a primary concern.

Unfortunately, the calculations used to determine the volume of water to be delivered downstream were based upon precipitation data derived from abnormally moist periods, leading to irrigation shortfalls during times of drought. The compacts required the states to make up the deficits of water not delivered in any given year, and exerted pressure on the distribution of water within each state. Thus the local authorities in New Mexico were required to deliver water downstream even when it threatened to seriously impair local irrigators. This is an issue of scale: the compacts are regional; the stress upon local irrigators is local. It is at the mid-scale of local government that we look for a solution to this quandary.

While the interstate compacts and international treaties demanded a quantum of water delivered annually, this was based upon an assumption about availability and end use. Furthermore, it had been discovered in the 1930s that the hydrologic functions of surface water and groundwater are interrelated, so that excessive withdrawals of groundwater to offset shortfalls in surface water effectively reduce surface flows, placing stress on the riparian zone and a reduction in its biodiversity and productivity (Phillips et al., 2011). The passage of the National Environmental Policy Act in 1969, and subsequent federal legislation such as the Clean Water Act (1972) and the Endangered Species Act (1973), introduced a broader series of concerns that did not mesh well with the engineering solutions. The need to provide habitat for the Rio Grande silvery minnow (Hybognathus amarus) introduced new design complexities based upon nonmonetary values (Porter \& Massong, 2004). More recently, agricultural researchers have determined that numerous ecosystem services derive from water flow in acequias (Rivera, 1998). As federal government agencies begin to clarify the means of determining environmental values, the administration of water law promises to become more nuanced.

Future populations in the region will require potable water resources produced by healthy and dynamic watersheds (Brown \& Rivera, 2000). Rural irrigation communities protect common pool resources; their management of natural resources plays a critical role in the survival of hydrologic systems providing for non-agricultural purposes, including urban and industrial uses, and the provision of ecosystem services. The persistence of these systems requires the protection of the relationship between land and water (Fernald et al., 2007; Ortiz et al., 2007; Van Ness, 1987). 


\section{New Mexico: Law and regulation}

The passage of legislation following the acquisition of New Mexico by the United States falls into two categories: territorial law and state statute. The territorial legislation began in 1851 and 1852, as noted above, with the incorporation of traditional practice into law. As noted by Clark (1987), water law remained fundamentally unchanged until the end of the territorial period, with two important exceptions.

In 1907 the territorial legislature passed a comprehensive water code referred to as the "Acequia Act" that has served as the framework of state water policy, law, and regulation since that time. As Fort et al. (2012) note, "Although lawmakers intended to protect the community acequias and other traditional institutions, after 1907 the Anglo sociocultural framework increasingly dominated water policy." This law centralized the administration of water through the creation of the office of what was to become the State Engineer. The law also provided for the severance of water rights from irrigated land, with transfer to other locations and uses.

Following admission to statehood in 1912, a substantial amount of activity occurred around water allocation within a regulatory framework, as well as periodic amendments to the 1907 water code. A number of statutes address fundamental distinctions such as between surface water and groundwater, and between regulatory administrative authorities, primarily the Office of the State Engineer and the Interstate Stream Commission, who oversee management of the state's streams and groundwater and delivery to downstream users respectively.

In 1987 the state of New Mexico initiated statewide water planning. Goals were to develop an "inventory of quantity and quality of water resources, population projections and other demands under a range of conditions, edit determination of how those demands might be met under existing rights, supplies, agreements, and court decrees" (Fort et al., 2012).

The State Water Plan Act of 2003 called on the Interstate Stream Commission to initiate regional water planning to cover all of the declared basins within the state. The State Water Plan that resulted established objectives for water use and allocation in a general fashion, and was updated in 2008 and 2009 in the face of diminishing snowpack and a future of attenuated water supply.

In north-central New Mexico, the area with the most numerous and vibrant acequia communities, four regional water plans were completed between 2003 and 2008, all of which called for protection of the acequia systems and landscape (Figure 3). 


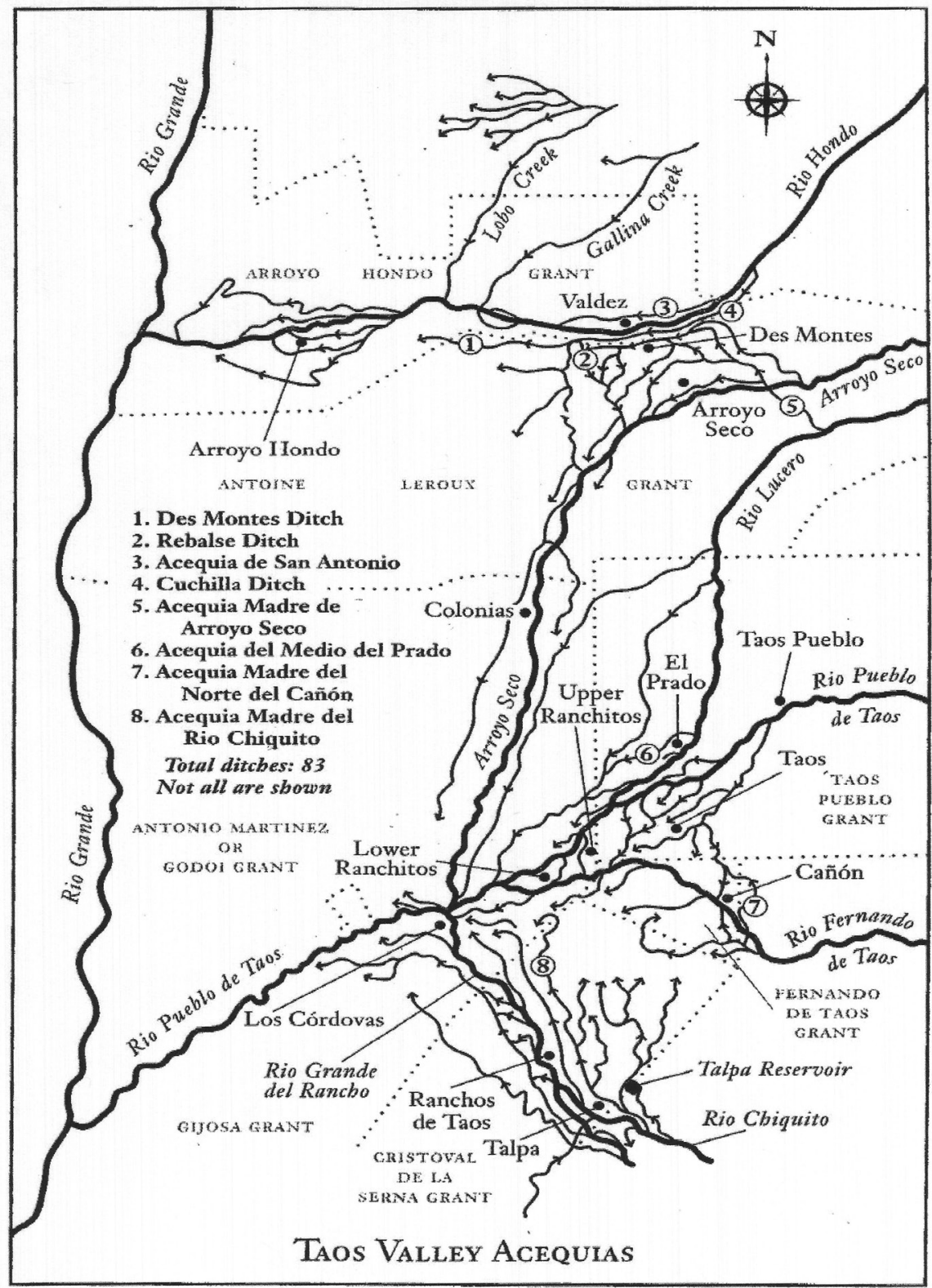

Figure 3. Distribution of acequia systems in the Taos Valley

Source: Rivera (1998, p. 167). Reproduced with permission. 
New Mexico statute assigns authority for the subdivision of property to municipal (Chapter 3) and county (Chapter 47) governments. ${ }^{3}$ The Office of the State Engineer reviews requests from county commissions to evaluate county-level subdivision proposals to assure they comply with the New Mexico Subdivision Act (1978 as amended) and County Subdivision Regulations (1978 as amended), to ensure that adequate water rights are available to support the development.

Water law is administered by the state of New Mexico; local land use is generally administered at the county and municipal levels. This represents a lack of articulation between two different levels of government that can become problematic when water use, land use, maintenance of habitat, and environmental services are in tension (Fort et al., 2011, 2012). It also poses difficulty when rural areas are subject to development pressures and encroachment by non-rural land uses.

The origin of the state statutes governing community ditch associations is rooted in the custom and tradition of Spanish and Mexican practices governing water rights. Early formal aspects of acequia custom provided for diversion of waters, a water allocation system, and provisions for return flow (Brown \& Rivera, 2000). Within these key elements, there was a great deal of local variation because the purpose was a practical resolution of local conditions governing the allocation of water during scarce times rather than uniformity of practice. Nonetheless, the authority for decision-making was grounded in the state, initially the Spanish crown and subsequently the Republic of Mexico. The Anglo-American civil legal structure increasingly demanded uniformity of practice, and it is by conformity to formal regulations that local acequia associations acquire the status of political subdivisions of the state.

While acequia associations were recognized as corporate bodies in 1895, statute law increasingly standardized governance and decision-making procedures for them in the 20th century, beginning with the 1907 New Mexico water code (Fort et al., 2012). Subsequent amendments to the 1907 law have expanded the authority of recognized acequia associations - which the Office of the State Engineer assumes to number around 800 - including a right to appeal decisions by the state engineer; to acquire and transfer water rights and to protect rights so acquired against loss for non-use; to enter into contracts for the construction, repair, and maintenance of physical irrigation infrastructure; and to exercise the right of refusal for the transfer of water rights from their jurisdiction and to protest the transfer of rights elsewhere if it is deemed that this would negatively affect the hydrological function of the acequia and its attendant water rights. ${ }^{4}$

3 New Mexico statutes and codes. Chapter 47: Property Law. Article 6- County Subdivisions. http://statutes.laws.com/new-mexico/chapter-47/article-6.

4 Section 72-7-1, New Mexico Subdivision Act (NMSA) 1978 as amended (1971); Section 73-3-55.1 NMSA 1978; Section 73-2-21.1 NMSA 1978; and Section 73-2-21 (E) NMSA 1978 and/or Section 73-3-4.1 NMSA 1978. 
It is the last of these amendments that offers the clearest current means for collaboration between the acequia associations and municipal and county governments for the protection of habitat, identity, and water rights. The law passed in 2003 allows acequia associations to intervene in proposed water transfers if their by-laws have been amended to include the statute language authorizing them to do so. ${ }^{5}$

\section{Contemporary acequia culture and rural regional planning}

Acequia associations are responsible for repair and maintenance of the hydraulic works, access to the ditches for cleaning and release of water from the main ditch into lateral ditches, supervising the allocation and distribution of water, and ensuring the obligatory dues payments and proper irrigation behavior of parciantes (irrigators).

Counties are in a position to mitigate competing land uses through zoning ordinances or through community planning. The traditional acequia communities can strengthen and even reestablish their historical function through collaboration with local governments' regulatory authority over land use, and can open the possibility of comprehensive water planning by regional authorities. Given that there are about 800 such acequia systems throughout the drainages of New Mexico, their vitality represents a key element in rural infrastructure (Fort et al., 2011; Rivera, 1998).

\section{Land use}

As land use regulation is primarily the province of county planning authorities, there is no necessary relationship between the assignment of purpose to real property and rights to irrigation water. However, counties have it within their powers to protect elements of land use that are considered of high social and ecological value; this can include the viability of acequia culture and management. Consequently, some counties have taken steps through their land use planning and zoning processes to protect acequia systems.

\footnotetext{
5 The Office of the State Engineer currently has routine communication with 500 of the 800 acequia associations in the state, and officials informally estimate that as many as 95 percent of those 500 have adopted enabling language into their by-laws (personal communication, May 14, 2013). Others consider 95 percent to be an exaggerated level, but acknowledge the increasing numbers of acequia associations adopting such language.
} 


\section{Subdivision ordinances and zoning}

In 2002, the Rio Arriba Board of County Commissioners adopted the Rio Arriba Agricultural Protection and Enhancement Ordinance, in recognition of the threat posed by rampant division of land for development. Before this time, state statutes had restricted such 'lot splits' to four from a single property over the course of two years. But legislative reforms did not address the concentration of dwellings, wells, and wastewater treatment on the divided parcels; potential threats to irrigation ditches that had served the previously undivided property; or the removal of agricultural land itself from that use.

In passing the ordinance, the county commission aimed to "protect and enhance the agricultural lands, the acequia systems, and the ground and surface water resources of Rio Arriba County by establishing criteria for review and approval of land use zoning, subdivisions, or division of land, located within irrigated agricultural lands" (Rio Arriba County, 2002). The ordinance addressed clustering of residential sites; conservation of irrigated agricultural land and water resources; contamination of groundwater and surface water from seepage; and protection of historical settlement patterns and visual amenities in service of general public health, safety, and welfare.

What had stimulated this action was that, because residential sites had historically been developed upslope from the irrigation ditches which themselves fed irrigated land farther downslope by gravity flow, the uncoordinated division of private property for non-agricultural purposes rendered prime productive land widely inaccessible for irrigation and morcellated it into less useful sizes.

The ordinance was a countywide approach to manage otherwise unplanned and unconstrained land uses that undercut custom, culture, and function of irrigated agricultural communities.

\section{Community planning}

In 2002, the Santa Fe County Commission adopted an ordinance affirming the community-level planning for traditional and contemporary communities "... to create a process whereby community members and the County jointly learn and document how development and growth both impact and can be directed to benefit individual communities throughout the county, within the context of and according to the principles of the County Growth Management Plan" (Santa Fe County, 2002). This ordinance allowed for local community purposes and values to define planning for the settlement in question. It distinguished between the needs and dispositions of the residents of historical communities, and those of more recent residents of contemporary subdivisions. 
Subsequently, the county addressed a needed revision of comprehensive land use planning by adoption in 2010 of the Santa Fe County Sustainable Growth Management Plan. This plan recognized the importance of protecting acequia systems and related water resources as a means of extending local agricultural production, irrigation water resources, and environmental services (Santa Fe County, 2010).

The principles in the updated 2010 plan, combined with the 2002 ordinance, opened the way for county planning staff to bridge land use and water rights issues. In each community participating in an updated planning effort, there was an opportunity for local acequia associations to raise key issues related to physical access, preservation, and functionality of the historical irrigation ditch systems. In some communities, the ditches were no longer in operation; in others, the irrigation issues were so contentious that local communities did not wish them to be included in local plans. In others, however, where ditches and ditch associations were still vibrant and supported local irrigation, they were considered a necessary element of the formal community plan that would be officially recognized by the Board of County Commissioners. Where local communities affirm the importance of acequias as part of the local infrastructure, the acequias are mapped into the local land use plan and the access of a buffer zone included as a living element to be considered in future development deliberations. When the community plans are approved by the county commission, they are considered to amend the county land use plan itself.

This critical juncture between land use planning and the viability of acequia systems opens the groundwork for a more formalized approach to land use designation at the county level. Under this arrangement, acequia landscapes can be defined through a "land typology zoning" that emphasizes the importance of these traditional and ecologically critical systems, perhaps by offering incentives for their preservation as well as other protections for their continued use. ${ }^{6}$

\section{Environmental challenges}

As Fernald et al. (2007), Ortiz et al. (2007), Rivera (1998), and Van Ness (1987) have all observed, the acequia systems play an important role in preserving ecosystem health by recharging shallow groundwater systems and extending riparian habitat. Coupled with a concern for the purity of water resources embodied in the National Environmental Policy Act, the Clean Water Act, and the Endangered Species Act, state and local governments have acted to protect acequia systems from contamination. A recent (2013) case is the adoption of an ordinance by Mora County in north-central New Mexico forbidding hydraulic fracturing ("fracking") for recovery of shale gas. Mora County Commission

6 S. Ijadi, Santa Fe County Senior Planner, personal communication, April 15 and May 8, 2013. 
Chairman, John Olivas, is quoted as explaining the motive for the ordinance in several ways, including that "Our acequias and our irrigation canals are dry, so the whole idea is resource protection" (Montoya Bryan, 2013).

\section{The contemporary acequia system and rural regional planning}

\section{Functionality}

Several studies in the past decade have affirmed the important role of acequia systems in providing ecosystem services. Among the possible benefits identified are "diluting agricultural chemicals or septic tank leachate in shallow groundwater, providing groundwater recharge to shallow wells, and providing delayed return flow to the stream thus maintaining in-stream flow after peak runoff periods" (Fernald \& Guldan 2006) and "sustain[ing] riparian vegetation along the main ditch and side ditches" (Fernald et al., 2007). Tarlock (2000) argues that federal legislation protecting water quality might lead to a reconnection of water rights and land property rights on a watershed basis. Roybal (2012) has developed a method for measuring the functionality of acequias, including hydrologic, agronomic, and social parameters. Miller (2013) has demonstrated how the continued operation of historical acequia systems has actually expanded the riparian zone in one case by as much as 10 percent since 1965 , to the benefit of density and diversity of vegetation and habitat types.

\section{Mutuality}

The social fabric that bound these irrigation communities together has been challenged by the changing political economy of the region since 1945:

In the decades after World War II, population growth, social mobility and technology exposed young people in the formerly isolated villages of northern New Mexico to a popular culture that offered alternatives to the hard work of farming. Market forces gave a new, monetary meaning to the concept of water rights. These factors have influenced norms and altered parciantes' understanding of the arrangements that determined their relationship to the acequia institution. (Brown \& Rivera, 2000, p. 26)

However, recent analysis of acequia systems suggests that despite the fact that irrigated agriculture in northern New Mexico is no longer the mainstay of the domestic economy, people continue to uphold the importance of acequias 
through active participation in maintenance and operation of the ditch systems for social and economic purposes - part of a mixed economic strategy combining crop and livestock production with wage labor (Roybal, 2012).

\section{Legitimacy}

State and federal law affirm the standing of acequia associations as corporate bodies and political subdivisions by defining their structure, upholding their decision-making authority, and providing grants and loans for them to carry out their work (Lovato, 1974; NMAA, 2010). The large body of statutes governing water rights, use, and administration has also increasingly formalized and strengthened their purposes and authority over time.

State regulatory authority has created the function of acequia liaison in the Office of the State Engineer to act as interface between the acequia associations and the Acequia Construction Program. The state legislature created the New Mexico Acequia Commission in 1993 "... to advise the governor, the New Mexico Interstate Stream Commission and the U.S. Army Corps of Engineers on what criteria should be used to determine priorities for rehabilitating acequias under a ... federal funding program."7 The purpose of regional water planning has been to rationalize a diverse and varied set of practices in the interest of predicting existing supply, measuring it against presumed future demand, and honoring commitments to provide water downstream under the obligations of the interstate compacts.

The combined strategies of zoning, community planning, and environmental protection at the local government level, along with regional water planning initiatives at the state level, are serving to complement state statutes governing water resources policy that have empowered acequia associations to intervene in proposed transfers of water rights, maintain access to irrigation ditches, acquire acequia water rights directly, and administer grants for the improvement of the acequias.

\section{Conclusion}

This convergence of acequia, local, state, and federal government actions, although not part of an intentionally unified strategy, nonetheless offers potentially powerful instruments to protect this historical, holistic approach to sustainable land and water use. But the broader state and federal legal contexts only constitute a shell within which daily aspects of land use and the provision of water are carried out. If land use and water rights decisions were left to

7 Retrieved from http://www.nmacequiacommission.state.nm.us/. 
state authorities, they would likely align with dominant regional economic and political interests. Because of the direct and persistent engagement of local communities, water rights and their distribution serve those broader-thanmonetary beneficial uses and continue to support the vitality of historical irrigation communities. This demonstrates how traditional knowledge based on experience along with citizen activism can influence the means by which public policy is implemented to the benefit of historical communities.

This is not to suggest that defense of traditional water rights and irrigation practices alone will sustain traditional land use. There are powerful economic pressures to transfer water rights and sell agriculturally productive land in an area that has been land rich and cash poor. But the marriage of traditional water rights and water management with land use regulation through zoning ordinances and the prospect of regulated land classification are important tools to reattach water to land in the interest of watershed health. The benefit is not only to local communities but to the broader needs for water for consumers downstream in a given drainage, and ultimately in other states.

Regional planning needs to consider physical infrastructure as one of its charter ingredients, and provision of potable water for irrigation and non-agricultural consumption is a requisite element of that infrastructure. The ability to preserve hydrological, economic, and social functions through the public-private cooperation between acequia communities and local governments offers an important step forward.

\section{References}

Brown, J. R., \& Rivera, J. A. (2000, June). Acequias de Común. Paper presented at Eighth Biennial Conference of the International Association for the Study of Common Property, May 31 - June 4, Bloomington, Indiana.

Clark, I. G. 1987. Water in New Mexico. Albuquerque: University of New Mexico.

Cook, E. R., Seagar, R., Heim, R. R., Jr., Vose, R. S., Herweijer, C., \& Woodhouse, C. (2009). Megadroughts in North America: Placing IPCC projections of hydroclimatic change in a long-term palaeoclimate context. Journal of Quarternary Science. Advance online publication. doi: 10.1002/jqs.1303

Dunbar-Ortiz, R. (2007). Roots of resistance. Norman: University of Oklahoma.

Ebright, M. (2001). Sharing the shortages. New Mexico Historical Review, 76(1), 3-45.

Fernald, A. G., Baker, T. T., \& Guldan, S. J. (2007). Hydrologic, riparian, and agroecosystem functions of traditional acequia irrigation systems. Journal of Sustainable Agriculture, 30(2), 147-171. 
Fernald, A. G., \& Guldan, S. J. (2006). Surface water-groundwater interactions between irrigation ditches, alluvial aquifers, and streams. Review in Fisheries Science, 14, 79-89.

Fort, D. D., Bushnell, D., \& Alexander, K. (2011). Land and water: Making the connection. Albuquerque: Utton Center, University of New Mexico School of Law.

Fort, D. D., Bushnell, D., \& Alexander, K. (2012). Water matters! Albuquerque: Utton Center, University of New Mexico School of Law.

Greenleaf, R. E. (1972). Land and water in Mexico and New Mexico 1700-1821. New Mexico Historical Review, 47(2), 84-112.

IPCC (Intergovernmental Panel on Climate Change). (2007). Climate change 2007. Geneva: United Nations Environment Programme.

Lovato, P. (1974). Las acequias del norte. Taos, NM: Four Corners Regional Commission, New Mexico State Planning Office, Kit Carson Memorial Foundation, Inc.

Meyer, M. C. (1984). Water in the Hispanic southwest. Tucson: University of Arizona.

Miller, A. R. (2013). Assessing change and resilience in a northern New Mexico acequia irrigation community. MWR/MCRP thesis. Albuquerque: University of New Mexico.

Montoya Bryan, S. (2013, May 1). Mora Co. bans oil, gas development. Albuquerque Journal. Retrieved from http://www.abqjournal.com/main/2013/05/01/biz/ mora-co-bans-oil-gas-development.html

NMAA (New Mexico Acequia Association). (2010). Acequia governance handbook. Santa Fe: New Mexico Acequia Association.

Ortiz, M., Brown, C., Fernald, A., Baker, T. T., Creel, B., \& Guldan, S. (2007). Land use change impacts on acequia water resources in northern New Mexico. Journal of Contemporary Water Research \& Education, September(137), 47-54.

Ostrom, E. (1990). Governing the commons. Cambridge: Cambridge University Press.

Phillips, F. M., Hall, G. E., \& Black, M. E. (2011). Reining in the Rio Grande. Albuquerque: University of New Mexico.

Porter, M. D., \& Massong, T. M. (2004). Habitat fragmentation and modifications affecting distribution of the Rio Grande silvery minnow. GIS/Spatial Analyses in Fishery and Aquatic Sciences (pp. 431-432). US Bureau of Reclamation, Fishery and Aquatic GIS Research Group.

Rio Arriba County. (2002). County of Rio Arriba: Agricultural Protection and Enhancement Ordinance-Appendix Q: Rio Arriba County Subdivision Land Regulations. Adopted January 31, 2002.

Rivera, J. A. (1998). Acequia culture: Water, land, and community in the Southwest. Albuquerque: University of New Mexico. 
Rivera, J. A., \& Glick, T. F. (2002, July). The Iberian origins of New Mexico's community acequias. Paper presented at the XIII Congress of the International Economic History Association, Buenos Aires. Retrieved from http:// taosacequias.org/Documents/GlickRivera409.pdf

Roybal, M. (2012). Measuring acequia functionality. MWR/MCRP thesis. Albuquerque: University of New Mexico.

Santa Fe County. (2002). Ordinance No. 2002-3. Adopted March 12, 2002.

Santa Fe County. (2010). Santa Fe County Growth Management Plan. Adopted by the Board of County Commissioners by resolutions 2010-210 and 2010-225.

Simmons, M. (1969). Settlement patterns and village plans in colonial New Mexico. Journal of the West, 8(1), 7-21.

Simmons, M. (1972). Spanish irrigation practices in New Mexico. New Mexico Historical Review 47(2), 135-150.

Tarlock, A. D. (2000). Reconnecting property rights to watersheds. William \& Mary Environmental Law and Policy Review, 25(1), 69-112.

Tyler, D. (1995). The Spanish colonial legacy and the role of Hispanic custom in defining New Mexico land and water rights. Colonial Latin American Historical Review, 4(2), 149-165.

Van Ness, J. R. (1987). Hispanic land grants: Ecology and subsistence in the uplands of northern New Mexico and southern Colorado. In C. L. Briggs \& J. R. Van Ness (Eds.), Land, water, and culture: New perspectives on Hispanic land grants. Albuquerque: University of New Mexico.

Zeiler, E. (2013). Office of the State Engineer. Santa Fe: New Mexico. 
This text taken from Human Ecology Review Volume 20, Number 2, 2014, published 2014 by ANU Press, The Australian National University, Canberra, Australia. 